\title{
Predictive value of copeptin as a severity marker of community-acquired pneumonia
}

Gamal Baheeg Mohamed ${ }^{1}$, Madeha Abdellah Saed ${ }^{2}$, Abdelhakeem Abdelmohsen Abdelhakeem ${ }^{3}$, Kalid Salah $^{4}$, Abdelrahman Mamdouh Saed ${ }^{5}$

${ }^{1}$ MD, Professor, Department of Pediatrics, Minia University, Minia, Egypt

${ }^{2}$ Lecturer, Department of Pediatrics, Minia University, Minia, Egypt

${ }^{3}$ MD, Assistant Professor, Department of Pediatrics, Minia University, Minia, Egypt

${ }^{4}$ MD, Assistant Professor, Department of Clinical Pathology, Minia University, Minia, Egypt

${ }^{5}$ M.Sc., Resident of Pediatrics, Department of Pediatrics, Minia University, Minia, Egypt

Type of article: Original

\begin{abstract}
Background: Pneumonia is the leading cause of death in children. Few studies have explored the predictive value of copeptin in pediatric pneumonia.

Aim: This study aimed to assess the role of copeptin as a marker of severity of community-acquired pneumonia (CAP).

Methods: This prospective case-control study was carried out at Minia University Children's Hospital in Minia (Egypt) from January to December 2016. Eighty children aged from 2 months to 42 months were enrolled in this study and were classified into group 1 (40 children with clinical, laboratory and radiological evidence of pneumonia) and group 2 (40 apparently healthy control). Serum copeptin level was assayed for all enrolled children.

Results: Mean serum copeptin level was significantly higher in pneumonic patients $(985.7 \pm 619) \mathrm{pg} / \mathrm{ml}$ compared to controls $(519 \pm 308.2) \mathrm{pg} / \mathrm{ml}(\mathrm{p}<0.001)$. Serum copeptin was significantly elevated in survivors of pneumonia more than non-survivors $(\mathrm{p}=0.001)$. Also, copeptin was significantly higher in the group of non-survivors (1811.8 \pm 327.1$)$ compared to $745.4 \pm 472.5$ for survivors $(\mathrm{p}=0.01)$. There was a significant positive correlation between serum copeptin levels and the degree of respiratory distress $(\mathrm{p}=0.02)$.

Conclusion: Copeptin seems a reliable and available predictor marker for assessing the severity and prognosis of pediatric community acquired pneumonia.
\end{abstract}

Keywords: Copeptin, Community acquired pneumonia, Outcome

\section{Introduction}

Childhood pneumonia is an important cause of morbidity in the developed world, and morbidity and mortality in the developing world. Community-acquired Pneumonia is a major cause of morbidity and mortality in children less than five years old. The World Health Organization (WHO) estimated that lower respiratory tract infection (LRTI) is responsible for approximately $20 \%$ of deaths in children less than five years old, worldwide, $90 \%$ of which is pneumonia (1). The highest mortality from childhood respiratory infection is seen in resource-limited countries and in children younger than 24 months of age (2). Diagnosis of community-acquired pneumonia is primarily based on the physical examination and history of the patient, and when needed, knowledgeable use of chest radiographs and laboratory tests (3). In order to deal with early onset of pneumonia, a search for new diagnostic markers is imperative, particularly as there is no widely-used scale that exists to rate CAP severity in children, and the most recent set guidelines concerning indications for hospitalization, are dependent upon general opinion rather than on evidence-based medicine. Copeptin, which is a peptide of 39 amino acids, is the C-terminal component of proArginine vasopressin (AVP) which is discharged along with AVP as the precursor peptide is processing (4).

\section{Corresponding author:}

Assistant Professor Dr. Abdelhakeem Abdelmohsen Abdelhakeem, Department of Pediatrics, Minia University, Minia, Egypt. Tel: +20.1223303608, Email: aboueyad1@yahoo.com

Received: February 14, 2017, Accepted: April 15, 2017, Published: July 2017

iThenticate screening: April 15, 2017, English editing: June 12, 2017, Quality control: July 02, 2017

(C) 2017 The Authors. This is an open access article under the terms of the Creative Commons Attribution-NonCommercialNoDerivs License, which permits use and distribution in any medium, provided the original work is properly cited, the use is non-commercial and no modifications or adaptations are made. 
Evidence shows copeptin to be more superior to cortisol in determining stress levels, as cortisol is further downstreamed in the stress response, has a strong circadian rhythm and is also difficult to measure as a free hormone (5). Copeptin has an active role in pneumonia and respiratory illness and it is superior to traditional inflammatory markers in patients with community-acquired pneumonia (6) This novel biomarker seems useful in predicting severity and complications in severe pneumonia in adults $(7,8)$, but very few studies have explored the predictive value of these markers in children $(9,10)$. Our objective was to assess the role of copeptin as an early predictor of severity of community-acquired pneumonia.

\section{Material and Methods}

This was a prospective case-control study which included eighty children who attended Minia University Children's Hospital during the period from January to December 2016. Their age range was 2 months to 42 months and they were classified into two groups: Group 1) 40 children with clinical and radiological evidence of pneumonia, Group 2) forty apparently healthy children who attended for non-respiratory problems or serious medical condition. Any child below 2 months and above 42 months, children with chronic respiratory illness, dehydration or over hydration, any suspicion of CNS disorder (trauma, infection or increased intracranial pressure due to any cause), patients who had been hospitalized and treated for two or more days prior enrollments in the study, and patients' guardians who refused to participate in the study, were all excluded. All patients were subjected to full history taking, thorough clinical examination and radiological imaging by chest X-ray. All enrolled children were subjected to complete blood counts $(\mathrm{CBC})$, quantitative C-reactive protein (CRP), arterial blood gases ( $\mathrm{ABG}$ ), and serum copeptin by a commercial enzyme linked immunosorbent assay (ELISA) kit (WKEA MED SUPPLIES catalog. No WH-1768). Pediatrics Respiratory Severity Score was calculated for each patient. Patients with a score of $0-1$ were considered mild pneumonia, 2-3 moderate pneumonia, while patients with a score of 4-5 were considered severe pneumonia (11). The study was revised and approved by the scientific ethical committee of the faculty of medicine Minia University. Informed written consents were documented from all children's guardians. Two $\mathrm{ml}$ of venous blood was withdrawn and allowed to clot for 10-20 minutes before centrifugation for twenty minutes at 2000-3000r.p.m remove supernatant, if precipitation appeared, centrifuge again for copeptin assaying commercial enzyme linked immunosorbent assay (ELISA). Another $2 \mathrm{ml}$ of venous blood was withdrawn on EDTA for CBC, serum sodium and $\mathrm{C}$ reactive protein assay. Another micro sample of arterial blood on heparinized syringe was withdrawn for arterial blood gas (ABG) assaying. Data were analyzed by SPSS version 13 (SPSS Inc., Chicago, Illinois, USA), using descriptive statistics, Chi-Square, Fisher Exact Test, Independent-samples t-test, and Spearman's correlation.

\section{Results}

Demographic, clinical and laboratory data of the studied groups are illustrated in Table 1. Also, the Correlation between serum copeptin and clinical data in CAP patients is presented in Table 2. In the present study, there were significantly higher vital signs (heart rate, respiratory rate and temperature) were found in pneumonic patients when compared to controls ( $\mathrm{p}=0.001,0.001,0.034$ respectively). In CAP patients, 2 patients $(5 \%)$ presented with RD I, 15 patients (16\%) had RD II, 18 patients (47.5\%) had RD III and 5 patients (12.5\%) were presented RD IV. PRESS was moderate in 25 patients $(63 \%)$ and, severe in 15 patients $(37 \%)$. Serum copeptin was significantly elevated in pneumonic patients compared to healthy ones $(\mathrm{p}=0.001)$. There was a significantly higher level of copeptin level in non-survivor patients $(\mathrm{p}=0.01)$ compared to survived patients. There was significantly positive correlation between copeptin and PRESS $(\mathrm{p}=0.002)$. Regarding laboratory results, there was a significantly increased total leucocytic count and CRP ( $\mathrm{p}=0.001$ for both) and a significant decrease in $\mathrm{O}_{2}$ saturation and $\mathrm{PaO}_{2}(\mathrm{p}=0.001,0.002$ respectively) compared with controls. Apart from significantly positive correlation between serum copeptin and total leukocyte count that was found $(\mathrm{p}=0.02)$, no significant correlations were found with other laboratory variables. ROC curve (Figure 1) showed area under curve (AUC) of 0.62, with copeptin cut-off point of $527 \mathrm{pg} / \mathrm{mL}$ having sensitivity and specificity of $70 \%$ and $85 \%$, respectively, for diagnosis of pneumonia. 
http://www.ephysician.ir

Table 1. Demographic, clinical and laboratory data of the studied groups.

\begin{tabular}{|c|c|c|c|c|c|c|c|c|}
\hline \multicolumn{5}{|c|}{ Clinical data } & \multicolumn{4}{|c|}{ Laboratory data } \\
\hline \multicolumn{2}{|c|}{ Variable } & $\begin{array}{l}\text { Patients; } n \\
(\%) / \text { Mean } \pm \text { SD }\end{array}$ & $\begin{array}{l}\text { Controls; } \mathrm{n} \\
(\%) / \text { Mean } \pm \mathrm{SD}\end{array}$ & $\begin{array}{l}\mathrm{p}- \\
\text { value }\end{array}$ & Variable & $\begin{array}{l}\text { Patients; } \\
\text { Mean } \pm \text { SD }\end{array}$ & $\begin{array}{l}\text { Controls; } \\
\text { Mean } \pm \text { SD }\end{array}$ & $\begin{array}{l}\mathrm{p}- \\
\text { value }\end{array}$ \\
\hline \multicolumn{2}{|l|}{$\begin{array}{l}\text { Mean age } \\
\text { (months) }\end{array}$} & $12.6 \pm 8.6$ & $20.5 \pm 16.1$ & 0.3 & $\begin{array}{l}\text { Mean } \\
\text { CRP }\end{array}$ & $33 \pm 40.8$ & $7 \pm 0.5$ & 0.001 \\
\hline \multicolumn{2}{|l|}{$\begin{array}{l}\text { Sex: Male } \\
\text { Female }\end{array}$} & $\begin{array}{l}23(57.5) \\
17(42.5)\end{array}$ & $\begin{array}{l}28(70) \\
12(30)\end{array}$ & 0.2 & $\begin{array}{l}\text { Mean } \mathrm{Hb} \\
\text { level }\end{array}$ & $10.1 \pm 1.3$ & $10.8 \pm 1.5$ & 0.01 \\
\hline \multirow[t]{2}{*}{ Residence } & Rural & $46 \%$ & \multirow{2}{*}{------------ } & \multirow[t]{2}{*}{------- } & \multirow{2}{*}{$\begin{array}{l}\text { Mean } \\
\text { TLC } \\
x 1000\end{array}$} & \multirow[t]{2}{*}{$12.3 \pm 4.1$} & \multirow[t]{2}{*}{$7.2 \pm 2.3$} & \multirow[t]{2}{*}{0.001} \\
\hline & Urban & $54 \%$ & & & & & & \\
\hline \multicolumn{2}{|c|}{ Smoking in family } & $25(60)$ & $7(15)$ & 0.002 & $\begin{array}{l}\text { Mean } \\
\text { PLTx1000 }\end{array}$ & $414.5 \pm 147.7$ & $296.1 \pm 125.1$ & 0.001 \\
\hline \multicolumn{2}{|c|}{ Mean Weight (kg) } & $6.72 \pm 2.89$ & $7.83 \pm 3.26$ & 0.111 & $\begin{array}{l}\text { Mean } \\
\mathrm{HCO}_{2}\end{array}$ & $16.1 \pm 6.03$ & $22.9 \pm 3.1$ & 0.001 \\
\hline \multicolumn{2}{|c|}{$\begin{array}{l}\text { Mean Heart rate } \\
\text { (min) }\end{array}$} & $141.4 \pm 18.4$ & $102.6 \pm 14.7$ & 0.001 & $\begin{array}{l}\text { Mean } \\
\mathrm{PCO}_{2}\end{array}$ & $35.1 \pm 12.9$ & $36.9 \pm 4.9$ & 0.4 \\
\hline \multicolumn{2}{|c|}{ Mean RR (min) } & $55.5 \pm 10.3$ & $30.60 \pm 5.65$ & 0.001 & $\begin{array}{l}\text { Mean } \mathrm{O}_{2} \\
\text { saturation }\end{array}$ & $84.9 \pm 14.3$ & $97.7 \pm 2.1$ & 0.002 \\
\hline \multicolumn{2}{|c|}{$\begin{array}{l}\text { Mean temperature } \\
\left({ }^{\circ} \mathrm{C}\right)\end{array}$} & $38.55 \pm 0.62$ & $37.29 \pm 0.2$ & 0.034 & $\begin{array}{l}\text { Mean } \\
\mathrm{PaO}_{2}\end{array}$ & $63.8 \pm 19.8$ & $87.9 \pm 6.6$ & 0.001 \\
\hline \multicolumn{2}{|c|}{$\begin{array}{l}\text { Mean serum } \\
\text { Copeptin }\end{array}$} & $985.7 \pm 619.1$ & $519.5 \pm 308.2$ & 0.001 & Mean PH & $7.3 \pm 0.1$ & $7.3 \pm 0.07$ & 0.09 \\
\hline
\end{tabular}

Table 2. Correlation between serum copeptin and clinical data in CAP patients.

\begin{tabular}{|l|l|l|}
\hline \multirow{2}{*}{ Clinical variable } & \multicolumn{2}{|l|}{ Serum Copeptin } \\
\cline { 2 - 3 } & $\mathrm{r}$ & $\mathrm{p}$-value \\
\hline Weight $(\mathrm{kg})$ & 0.175 & 0.274 \\
& & \\
\hline Heart rate (/min.) & -0.017 & 0.918 \\
\hline Respiratory rate (/min.) & -0.069 & 0.668 \\
\hline Temperature $\left({ }^{\circ} \mathrm{C}\right)$ & -0.104 & 0.516 \\
\hline Respiratory distress (I, II, III, IV) & 0.151 & 0.346 \\
\hline PRESS (Pediatric Respiratory Severity Score). & 0.220 & $0.002^{*}$ \\
\hline
\end{tabular}

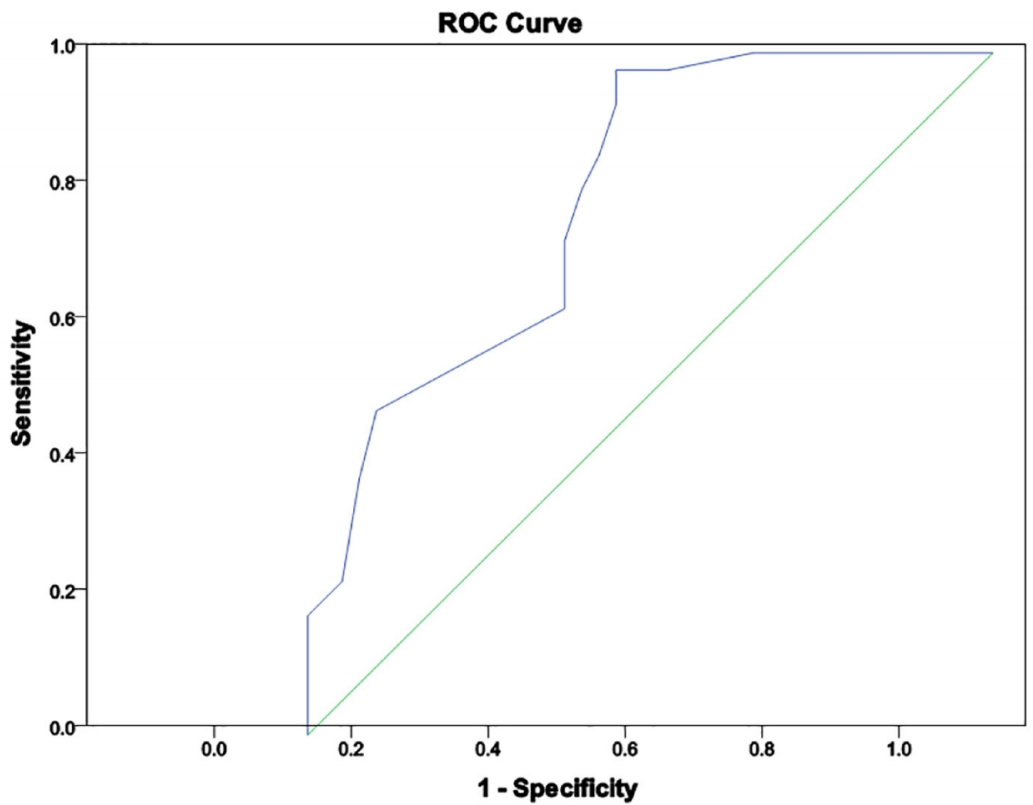

Figure 1. ROC curve analysis Copeptin level in CAP patients. 


\section{Discussion}

Pneumonia in children under 5 years of age is the major cause of mortality, and most of the cases involve community-acquired pneumonia (CAP) (12). In non-infectious diseases such as stroke, copeptin was proved to be a marker of severity. Copeptin also showed encouraging indications as a prognostic marker in CAP. This was proposed in a review by Katan et al. on adults with ventilator-associated pneumonia (5), and in a study in Switzerland by Müller et al. on lower respiratory tract infections (13). In later studies, copeptin levels were significantly lower in survivors. In the present study, serum copeptin levels are somewhat higher in pneumonic patients. This is in agreement with Du et al. (14) where median copeptin levels were much higher in children with pneumonia compared with healthy volunteers, and in that area, the present study confirmed those data. Also, Wrotek (15) and Jochberger et al. (16) reported that copeptin concentrations were significantly higher in ICU patients compared to controls. In pneumonia, gas exchange in the lungs causes changes in the AVP system (17). Copeptin is co-synthesized with AVP, it is found equally with AVP in the circulation, increasing copeptin concentration. , Copeptin concentration was found to increase with the disease severity in those diseases. Copeptin is an independent predictor of mortality in VAP $(18,19)$. Serum copeptin concentration of the grade V patients was significantly higher than those of the grade IV patients, grade I - III patients and the control group. Copeptin increases with more respiratory effort (20). Du et al (14) reported that copeptin is known to reflect the severity of pneumonia and it seems to correspond with complications of pneumonia in children. However, his study failed to confirm this observation, as it found no correlation between copeptin and pneumonia severity based on clinical and laboratory features. Copeptin concentration is affected according to the survival status and it was significantly elevated in nonsurvivors. In CAP, copeptin was an independent predictor of this disease, and may provide additional information about the severity of disease. Regarding due elevated NPV, copeptin gives scant evidence about predicting the etiology of CAP, despite its reliable prognostic value, because there is sizeable overlap in copeptin values among patients with varied etiologies of pneumonia (21). Krüger et al. expressed that it was clinically important to consider antibiotic therapy for accurate analysis of copeptin concentration along with concentration of other inflammatory biomarkers in CAP, because patients who survived that were treated with antibiotics, displayed considerably lower copeptin values in comparison to non-survivors, which can be explained by the reduction of circulation damage caused by sepsis (18). For patients with acute exacerbation of COPD, concentration of elevated copeptin predicts the final outcome, and acts as a risk factor for long-term clinical failure, irrespective of the patient's age, comorbidity, hypoxemia or functional pulmonary disorder (22). Comparing copeptin values in several etiologies of lower respiratory tract infections, Müller et al. conveyed that concentration of copeptin in patients with acute bronchitis and acute exacerbation of COPD was significantly greater in comparison to the control group. It was also revealed upon further examination, that there was no difference in copeptin concentration between acute bronchitis and acute exacerbation of COPD. Furthermore, patients who were diagnosed with CAP were proven to have the highest copeptin concentration. It is probable that merely a slight elevation of copeptin concentration in acute bronchitis and acute exacerbation of COPD reflects localized infection compared to the control group (13). Determining dyspneic patients at the highest risk for adverse outcomes is problematic because acute dyspnea can regularly occur for a number of reasons such as pulmonary, cardiac, or inflammatory causes (23). In these patients, copeptin secretion is probably connected with three possible mechanisms. Firstly, AVP released in heart failure is mainly driven by inadequate filling of arteries which activates the carotid sinus and aortic arch baroreceptors. Secondly, in severe COPD, AVP has a vasoconstrictive effect which is induced by hypoxia. Elevated concentration of AVP can compensate for the inadequate regulation of $\mathrm{V} 1$ receptors after exposure to ongoing hypoxemia. Finally, copeptin is significantly elevated in bacterial infection and febrile conditions (23). Our study revealed a significant positive correlation between serum copeptin and total leukocyte count of cases $(p=0.02)$. It seems that further studies on a larger scale are warranted to delineate the actual clinical utility of serum copeptin in diagnosis and prognosis of pediatric pneumonia. The limitations of the present study are the small sample size and the lack of work-up for viral and bacterial pneumonias.

\section{Conclusions}

In the present study, elevated copeptin was detected in children with pneumonia. Significantly higher levels were found in non-survivors than in survivors and levels are higher in children dying of the disease. The level of copeptin in pediatric pneumonia may predict adverse results.

\section{Acknowledgments:}

All members of the pediatric department at El-Minia Children University Hospital and the Department of Clinical Pathology are acknowledged for their help in completing this work. 


\section{Conflict of Interest:}

There is no conflict of interest to be declared.

\section{Authors' contributions:}

All authors contributed to this project and article equally. All authors read and approved the final manuscript.

\section{References:}

1) Black RE, Cousens S, Johnson HL, Lawn JE, Rudan I, Bassani DG, et al. Global, regional, and national causes of child mortality in 2008: a systematic analysis. Lancet. 2010; 375(9730): 1969-87. doi: 10.1016/S0140-6736(10)60549-1. PMID: 20466419.

2) Williams BG, Gouws E, Boschi-Pinto C, Bryce J, Dye C. Estimates of world-wide distribution of child deaths from acute respiratory infections. Lancet Infect Dis. 2002; 2(1): 25-32. doi: 10.1016/S14733099(01)00170-0. PMID: 11892493.

3) Otapchuk M, Roberts D, Haddy R. Community-Acquired Pneumonia in Infants and Children. Am Fam Physician. 2004; 70(5): 899-908.

4) Land H, Schutz G, Schmale H, Richter D. Nucleotide sequence of cloned cDNA encoding bovine arginine vasopressin-neurophysin II precursor. Nature. 1982; 295(5847): 299-303. doi: 10.1038/295299a0. PMID: 6276766.

5) Katan M, Müller B, Christ-Crain M. Copeptin: a new and promising diagnostic and prognostic marker. Crit Care. 2008; 12(2): 117. doi: 10.1186/cc6799. doi: 10.1186/cc6799. PMID: 18355399, PMCID: PMC2447549.

6) Kruger S, Ewig S, Giersdorf S, Hartmann O, Suttorp N, Welte T. Cardiovascular and inflammatory biomarkers to predict short- and long-term survival in community-acquired pneumonia: results from the German Competence Network, CAPNETZ. Am J Respir Crit CareMed. 2010; 182: 1426-34. doi: 10.1164/rccm.201003-0415OC. PMID: 20639437.

7) Christ-Crain M, Morgenthaler NG, Stolz D, Müller C, Bingisser R, Harbarth S, et al. Pro-adrenomedullin to predict severity and outcome in community-acquired pneumonia [ISRCTN04176397]. Crit Care. 2006; 10(3): R96. doi: 10.1186/cc4955. PMID: 16805922, PMCID: PMC1550935.

8) Morgenthaler NG, Struck J, Alonso C, Bergmann A. Assay for the measurement of copeptin, a stable peptide derived from the precursor of vasopressin. Clin Chem. 2006; 52(1): 112-9. doi: 10.1373/clinchem.2005.060038. PMID: 16269513.

9) Michels M, Djamiatun K, Faradz SM, Koenders MM, de Mast Q, van der Ven AJ. High plasma midregional pro-adrenomedullin levels in children with severe dengue virus infections. J Clin Virol. 2011; 50(1): 8-12. doi: 10.1016/j.jcv.2010.09.008. PMID: 20952250.

10) Sarda Sanchez M, Hernandez JC, Hernandez-Bou S, Teruel GC, Rodriguez JV, Cubells CL. Proadrenomedullin usefulness in the management of children with community-acquired pneumonia, a preliminar prospective observational study. BMC Res Notes. 2012; 5: 363. doi: 10.1186/1756-0500-5-363. PMID: 22818355, PMCID: PMC3431981.

11) Miyaji1Y, Sugai K, Asako N, Miho K, Shoichi N, Hiroyuki T, et al. Pediatric Respiratory Severity Score (PRESS) for Respiratory Tract Infections in Children. Austin Virology and Retrovirology. 2015; 1(1): 1-7.

12) Rudan I, O’Brien KL, Nair H, Liu L, Theodoratou E, Qazi S, et al. Epidemiology and etiology of childhood pneumonia in 2010: estimates of incidence, severe morbidity, mortality, underlying risk factors and causative pathogens for 192 countries. J Glob Health. 2013; 3(1): 010401. doi: 10.7189/jogh.03.010401. PMID: 23826505, PMCID: PMC3700032.

13) Muller B, Morgenthaler N, Stolz D, Schuetz P, Müller C, Bingisser R, et al. Circulating levels of copeptin, a novel biomarker, in lower respiratory tract infections. Eur J Clin Investig. 2007; 37(2): 145-52. doi: 10.1111/j.1365-2362.2007.01762.x. PMID: 17217381.

14) Du JM, Sang G, Jiang CM, He XJ, Han Y. Relationship between plasma copeptin levels and complications of community-acquired pneumonia in preschool children. Peptides. 2013; 45: 61-5. doi: 10.1016/j.peptides.2013.04.015. PMID: 23659862.

15) Wrotek A, Jackowska T. Hyponatremia in children hospitalized due to pneumonia. Adv Exp Med Biol. 2013; 788: 103-8. doi: 10.1007/978-94-007-6627-3_16. PMID: 23835966.

16) Jochberger S, Mayr VD, Luckner G, Wenzel V, Ulmer H, Schmid S, et al. Serum vasopressin concentrations in critically ill patients. Crit Care Med. 2006; 34(2): 293-9. doi: 10.1097/01.CCM.0000198528.56397.4F. PMID: 16424705. 
17) Boeck L, Eggimann P, Smyrnios N, Pargger H, Thakkar N, Siegemund M, et al. The Sequential Organ Failure Assessment score and copeptin for predicting survival in ventilator-associated pneumonia. J Crit Care. 2012; 27(5): 523.e1-9. doi: 10.1016/j.jcrc.2011.07.081. PMID: 21958973.

18) Krüger S, Ewig S, Kunde J, Hanschmann A, Marre R, Suttorp N, et al. C-terminal provasopressin (copeptin) in patients with community-acquired pneumonia--influence of antibiotic pre-treatment: results from the German competence network CAPNETZ. J Antimicrob Chemother. 2009; 64(1): 159-62. doi: 10.1093/jac/dkp148. PMID: 19403654.

19) Seligman R, Papassotiriou J, Morgenthaler NG, Meisner M, Teixeira PJ. Copeptin, a novel prognostic biomarker in ventilator-associated pneumonia. Crit Care. 2008; 12(1): R11. doi: 10.1186/cc6780. PMID: 18252006 , PMCID: PMC2374597.

20) Zhao YF, Lin Y, Zhang WG. [Clinical significance of serum copeptin in patients with community-acquired pneumonia.]. Zhonghua Jie He He Hu Xi Za Zhi. 2009; 32(12): 911-4. PMID: 20193350.

21) Masiá M, Papassotiriou J, Morgenthaler NG, Hernández I, Shum C, Gutiérrez F. Pro-A-type natriuretic peptide and carboxy-terminal provasopressin may predict prognosis in community-acquired pneumonia. ClinChem. 2007; 53(15): 2193-201. doi: 10.1373/clinchem.2007.085688.

22) Stolz D, Christ-Crain M, Morgenthaler NG, Leuppi J, Miedinger D, Bingisser R, et al. Copeptin, C-reactive protein, and procalcitonin as prognostic biomarkers in acute exacerbation of COPD. Chest. 2007; 131(4): 1058-67. doi: 10.1378/chest.06-2336. PMID: 17426210.

23) Potocki M, Breidthardt $T$, Mueller A, Reichlin $T$, Socrates $T$, Arenja N, et al. Copeptin and risk stratification in patients with acute dyspnea. Crit Care. 2010; 14(6): R213. doi: 10.1186/cc9336. PMID: 21106053, PMCID: PMC3220005. 